In conclusion I have to point out, as shown by my investigations commenced four years ago, that farmyard manure laid on to the land is only rendered properly available to the crops by the action of bacteria as indicated above in connection with the natural humus. The inorganic forces have little action upon it, except in producing humic acid and other injurious matters.

The most of the soluble mineral substances in a mature soil, it may also be mentioned, are in the form of sulphate. They originate from the primary minerals as carbonate, but are soon altered, mainly by the ferrous sulphate. The sulphate unfortunately is not the most suitable form in which minerals can be presented to plants for absorption, for the simple reason that, being so stable in chemical union, it causes the loss of too much of the plant's energy in the interior of its body before it can be decomposed. It must be remembered that green plants decompose the compounds which enter their system before they utilize their elements or simpler forms in the elaboration of food.

Edinburgh, August 5.

\section{THE IMPERIAL INSTITUTE AT ST.} PETERSBURG. ${ }^{1}$

I November, 1885 , some months after the publication of Pasteur's discovery for the treatment of hydrophobia, an officer of the Russian Guards was bitten by a rabid dog. This officer having been sent to Paris to undergo the treatment, his Highness Prince Alexander Petrowitch d'Oldenburg established, at his own expense, a provincial laboratory at St. Petersburg, where Pasteur's treatment could be duly carried out. This establishment, however, soon proved to be too small for scientific investigations to be properly carried out therein, and it was decided to build a large laboratory in which researches might be made under the best possible conditions; accordingly the same enlightened nobleman bought a piece of ground of 37,464 square metres in extent, on which the present Institute is built.

The buildings comprise physiological, pathological, chemical, bacteriological, and epizootological sections, with their laboratories, under the direction of such men as Neucki, Winogradsky, and others. There is also a department where Pasteur's treatment is carried out, together with a small hospital for infectious cases. Each section is complete in itself, and all the arrangements are on the newest principles and on a very large scale. The expenses are defrayed partly by the Prince of Oldenburg and partly by public subscription, and the whole Institute compares favourably with any Institute in France or Germany.

The directors of the Institute publish every two or three months a volume embodying the scientific results obtained in the laboratories, and the first two numbers have now been published. As might be expected after what has just been said, their contents are of wide and varied interest. Neucki publishes some chemical researches on the microbe producing inflammation of the mammary glands of milch cows and goats, and his paper will specially interest those who in this country have followed the remarkable researches of Dr. E. Klein. Winogradsky gives an account of the various nitrifying organisms discovered by him in the soil of different countries. This author quotes the researches of Prof. and Mrs. Frankland, and of Prof. Warington, and though to some extent contradictory, Winogradsky's researches agree with those of the English observers in all essential particulars. This paper is certainly the most important which has as yet appeared on this vexed question. The results obtained by Pasteur's treatment in St. Petersburg

x "Archives de Sciences Biologiques publiées par l'Institut Impérial de Médecine Expérimentale à St. Pétersbourg," Vol. r, No. I et 2. form the subject of a paper by Kraïouchkine, and it may be mentioned that the treatment appears to have been as successful at St. Petersburg as in Piris.

The other papers refer to the chemical and physiological effects of tuberculin (Bujwid, Helman), to the transformation of nutritive media by the bacillus of diphtheria, and to the chemical composition of this micro-organism (Dzierzgowski and Rekowski), while Blachstein endeavours to draw a distinction between the bacillus coli communis and the bacillus typhi abdominalis, based on the chemical decompositions produced by these organisms in the media in which they grow. Lastly, Mizerski and L. Neucki give a critical résumé of the methods used to estimate the quantity of hydrochloric acid contained in gastric juice.

The researches which form the subjects of these papers are varied enough, and whilst congratulating their authors we may express the hope that the Institute will have a long and prosperous career. Our good wishes must be tinged with regret for ourselves-regret that there should not be a similar Institute in England, and regret also that there should be in this country a class of people who will oppose the establishment of such an Institute until a Bishop or Royal Duke has died of rabies.

M. ARMAND RufFer.

\section{NOTES}

LAST week much anxiety was felt as to the health of Sir Richard Owen. On Monday his condition was better, and the improvement, was maintained on Tuesday.

THE herbarium of the British Museum has acquired, by presentation from the widow, the very valuable collection of Muscineæ, made by the late Mr. George Davies, of Brighton. It comprises upwards of 20,000 specimens of mosses, hepaticæ, and lichens, partly gathered by Mr. Davies in Great Britain and on the Continent, partly communicated to him from New Zealand, Samoa, India, the West Indies, and America.

Prof. Hieronymus has been appointed curator of the Royal Botanical Museum at Berlin.

The Exhibition of the Photographic Society of Great Britain was opened on Monday at the Gallery of the Royal Society of Painters in Waterco lours. It will remain open till November ro.

WE regret to have to record the death of Mr. George Croom Robertson. He was fifty years of age, and only lately, in con. sequence of ill-health, resigned the professorship of Mind and Logic at University College, London, to which he was appointed in $\mathbf{1} 866$. Prof. Robertson was well known as a brilliant teacher of the subjects to the study of which he devoted his life, and as the editor of Mind. He was associated with Prof. Bain in the editing of Grote's "Aristotle," and was the author of the volume on Hobbes in Blackwood's series of "Philosophical Classics." He also contributed to the latest edition of the " Encyclopædia Britannica."

Dr. George Dixon Longstaff died at Wandsworth on Friday last in his ninety-fourth year. When a young man he was assistant to Dr. Hope, Professor of Chemistry at the University of Edinburgh, and he is believed to have been the first teacher of practical chemistry to medical students in this country. He was one of the founders and a vice-president of the Chemical Society of London.

Students of folklore will be sorry to hear of the death of Reinhold Köhler, librarian at Weimar, where he was born in 1830. He died on August 15. Dr. Köhler was a man of great learning, well known as an authority on the subject in which he was chiefly interested.

$$
\text { No. II96, VOL. 46] }
$$

